\title{
Kent İçi Ulaşımına Entegre Edilen Bisiklet Yolu Tasarımı ve Uygulaması: Kanada/Halifax Kenti Korumalı Bisiklet Yolları Örneği
}

\author{
Yelda Durgun Şahin ${ }^{1}$ \\ ORCID: 0000-0001-6708-9247
}

\section{Öz}

Bisikletler 21. yüzyılın ulaşım sistemini yeşil kılmak, enerji tüketimini ve karbon salınımını azaltmak, sağlıklı yaşam sürmek ve COVID 19 pandemi sürecinde sağhlklı ulaşımı destekler nitelikte olması gibi pek çok olumlu özelliğe sahip bir seyahat şekli olarak görülmektedir. Çalışmanın amacı, kent içi ulaşımına eklemlenen bisiklet yollarımın entegrasyon sürecinde, planlama ve tasarım ölçeğinde alınması gereken kararların uygulanmış örnek bir proje üzerinden incelenmesi olarak belirlenmiştir. Çalışma alanı olarak Kanada-Nova Scotia Eyaleti, Halifax kenti, South Park Street bölgesi seçilmiştir. Çalışma kapsamı üç aşamalı olarak kurgulanmıştır. İlk olarak, bisiklet yolları ve bağlantı noktaları için geliştirilen tasarım biçimlerinin uygulandığı yerler ve olumlu özellikleri ele alınmıştır. İkinci aşamada Halifax belediyesinin geliştirmiş olduğu üç farklı bisiklet yolu projesinin seçimi için değerlendirme kriterlerine yer verilmiş ve Halifax belediyesi ile halkın katılımo yönüne vurgu yapılmıştır. Üçüncü aşamada, uygulanan tasarımın kullanıcı için sağlamış olduğu olumlu ve olumsuz yönler alan çalışması yapılarak analiz edilmiştir. Çalışmanın sonunda güncel ve yurtdışında yapılan bir uygulamanın planlama ve tasarım süreci değerlendirilmiştir. Türkiye'de mevcut kent içi ulaşımına entegre edilecek bisiklet yolları oluşturmak için süreç yönetiminde kullanılabilecek temel karar önerileri sunulmuştur. Trafik sıkışıklığının büyük sorun haline geldiği günümüz büyük şehirlerinde, bisiklet kullanımının alternatif ve güvenli bir ulaşım türü olması nedeniyle konunun önemine dikkat çekilmek istenmiştir.

Anahtar Kelimeler: Kent içi ulaşım, bisiklet yolu, tasarım ve planlama süreci, Halifax/Kanada.

\footnotetext{
${ }^{1}$ Dr. Öğr. Üyesi, Adana Alparslan TürkeşBilim ve Teknoloji Üniversitesi, E-mail:ydurgunsahin@atu.edu.tr idealkent @ Kent Araştırmaları Dergisi 


\title{
Bicycle Route Design and Application Integrated in Urban Transportation: Sample of Cycle Paths in Canada/Halifax City
}

\author{
Yelda Durgun Şahin 2 \\ ORCID: 0000-0001-6708-9247
}

\begin{abstract}
Cycling is a form of travel with many positive features such as making the transportation system of the 21st century green, reducing energy consumption and carbon emissions, leading a healthy life, supporting healthy transportation that during the COVID 19 pandemics The aim of the study has been determined as the examination of the decisions to be taken at the planning and design scale in the integration process of bicycle lanes, which are attached to urban transportation, through an applied sample project. As the study area, Canada-Nova Scotia Province, Halifax city, South Park Street area was chosen. The scope of the study was structured in three stages. First, the places where the design forms are applied and their positive features are discussed. In the secondly, evaluation criteria were included for the selection of three different bicycle path projects developed by Halifax municipality. In the third stage, the positive and negative aspects of the applied design for the user were determined and analyzed on site. At the end of the study, the planning and design process of a current and international application was evaluated. Basic decision suggestions that can be used in process management to create bicycle paths in Turkey are presented.
\end{abstract}

Keywords: Urban transport, cycle path, design and planning process, Halifax/Canada.

\footnotetext{
${ }^{2}$ Asst.Prof, Adana Alparslan Türkeş Science and Technology University, E-mail:ydurgunsahin@atu.edu.tr idealkent @ Journal of Urban Studies 


\section{Giriş}

Düşünceli ve kararlı küçük bir grup yurttaşın

dünyayı değiştirebileceğinden asla şüphe etmeyin

İnsanbilimci Margaret Mead.

Mead'in belirttiği gibi herhangibir şeyi değiştirmek için öncelikle o iş için istekli, kararlı ve bilgili kişilerin biraraya gelerek o problemi çözmeleri gerekmektedir. Bisiklet yolları oluşturulurken, tek bir karar vericinin ya da az sayıda kriterin belirleyici olması, ya da bisiklet yolunun uygulanacağı çevreden bağımsız düşünülmesi yani bağlamdan kopuk olması, oluşturulan güzergâhın bisikletliler tarafından etkin bir şekilde kullanılamaması, bisiklet yolunun mevcut ulaşım ağına entegre olamaması ve bunların yanı sıra aşırı maliyet gibi sorunlar oluşturabilmektedir. Bu bağlamda Kanada/Nova Scotia Eyaleti, Halifax kenti özelinde her yıl değişen nüfusa bağlı olarak belirlenen sayıda kişiyi kapsayacak şekilde (2021 için bu sayı 20.000 kişi olarak belirlenmiştir) Belediye tarafından, öncelikli almak istedikleri hizmeti saptamak amaciyla evlere katılım daveti gönderilmektedir. Sonuçlar, acil ve uzun vadeli iş ve bütçe planlaması ile belediyeye rehberlik etmek için kullanılmaktadır. Belediyenin kamusal alanda vereceği hizmetleri acil, kısa ve orta vadede planlarken, önceliği halkın hizmet beklediği alanlarda katılımc bir politikayla sürdürmesi doğru bir yaklaşım olarak değerlendirilmiştir (Halifax Regional Municipality, 2021) Halifax Belediyesi kent içi ulaşımında kullanılan tabelaları, işaretleri ve trafik sinyali türlerini geliştirmek için Nova Scotia Motorlu Araç Yasası, Kanada Ulaştırma Birliği/TAC' nin (Transportation Association of Canada, 2021) ve NACTO (National Association of City Transportation Officials) Kentsel Bisiklet Yolu Tasarım Kilavuzu'nu profesyonel rehberlik aracı olarak kullanmaktadır.

Bisiklet yollarında uygun rotanın belirlenmesinde halkın katılımc rolü ve tasarım kılavuzlarının rehberliğiyle beraber, kullanılan yöntemler ile ilgili olarak mevcut yol koşullarını değerlendiren çeşitli çalışmalar yapılmıştır. Botma, bisikletlilerin bir araya gelme ve/veya bir yoldan geçme sıklığına dayalı olarak ayrılmış bir bisiklet şeridi için LOS (level of serves/hizmet kalitesi) kriterlerini tanımlamaktadır. Bu kriter bisiklet sürücüsünün bisiklet yolu algısını ölçmede kullandığı nitel bir ölçüttür (Hein, 1995, s.s.38-44). Texas Ulaştırma Bakanlığı ise, yol koşullarını dikkate alan bisiklet uygunluk değerlendirme yöntemi için bisiklet uygunluk puanı geliştirmiştir (Turner, Shafer ve Stewart, 1997, s. 49). Bazı araştırmalar, bisiklet kullanıcılarının stres seviyele- 
rini ölçerken (Sorton,1995, s.1079; Sorton,1994,s.s. 17-24), diğerleri, bisiklet güvenlik indeksi derecelendirmesini (BSIR)( Eddy,1996, s.312) kullanmak gibi mevcut yolun bisiklet hizmet seviyesini değerlendirmektedir. Landis Bisiklet etkileşimi için tehlike skoru kullanımını kullanıcılar üzerinde uygulayarak yöntemi doğrulamaktadır (IHS) (Landis, 1997).

Bu çalışma ile uygulaması yapılmış bir alanın planlama ve tasarım sürecinin değerlendirmesi ve uygulama sonrası tasarımın olumlu ve olumsuz yönlerinin tespit edilmesi açısından literatüre katkı sağlayacağı düşünülmüştür. Çalışma üç bölümde kurgulanmıştır. Çalışmanın ilk bölümünde, Halifax belediyesinin, kent içi bisiklet yolları uygulamaları için hazırlanmış olan tasarım kılavuzlarından faydalanılmış ve kent içi ulaşıma entegre edilen bisiklet yolları için geliştirilen tasarım şekillerine yer verilmiştir.

Çalışmanın ikinci bölümünde, Halifax belediyesinin bisiklet yollarının kent içine entegrasyonu için planlama ve tasarım süreci olan 2016-2019 yılları arasında almış oldukları kararlara yer verilmiştir. Seçilen örneklem alanı için uygulanmış olan bisiklet yolu tasarımı, uygulama öncesinde alınan planlama kararları ile tasarım süreci yönünden incelenmiştir. Çalışma bölgesi için hazırlanmış olan üç öneri tasarım, Ulaştırma Daimi Komitesi tarafından sürüş güvenlik konfor ve kolaylığı, kavşak güvenlik ve konforu, otobüs güvenlik ve konforu, daha geniş bisiklet ağına bağlantı, bisiklet yolunun Inglis street'e devam etmesi, yayaya etkisi, otobüslere etkisi, motorlu taşıtlara etkisi, ticari ve konut otoparkına etkisi, erişilebilir park alanına etkisi, taksi durağına etkisi, yeşil alan ve kent ormanına etkisi, bakım, sermaye maliyeti, genel kamu/paydaş desteği seviyesi değerlendirme kriterleri ile yapmış oldukları karşılaştırmalarına yer verilmiştir.

Çalışmanın üçüncü bölümünde, çalışma bölgesi olan South Park Street caddesinde uygulama sonrası yerinde tespit çalışmaları yapılarak tasarımın güçlü ve zayıf yönleri değerlendirilmiş ve fotoğraflanarak analiz edilmiştir.

Çalışmanın sonunda, bisiklet yolları oluşturulurken halkın taleplerine yer verildiği, çok farklı türleri bulunan bisiklet yolu tasarımlarının her tür alana uygulanamayacağı, uygulama alanının tüm yönleriyle iyi analiz edilerek tasarım kriterlerinin belirlenip, alana özel olarak uzman görüşü alınarak kriterlerin ağırlıklandırılmasının yapılması gerekliliği ve yapılacak bisiklet yolunun bağlamının tasarım kriterinde çok büyük öneme sahip olduğu görülmüştür.

Halifax kent içi ulaşım örneği olarak incelenen bu çalışma, Türkiye'de kent içi ulaşıma entegre edilecek yeni bisiklet yolları için yol gösterici olacağ1 düşünülmüştür. 
Bisikletler 21. yüzyılın ulaşım sistemini yeşil kılmak, enerji tüketimini ve karbon salınımını azaltmak, sağlıklı bir yaşam sürmek ve özellikle COVID 19 pandemi sürecinde sağlıklı ve güvenli bir ulaşım aracı olması gibi pek çok olumlu özelliğe sahip bir seyahat şekli olarak görülmektedir. Kentsel alanlarda bisiklet ağı oluşturmak, ulaşım aracı olarak bisiklet kullanımını teşvik etmenin önemli bir noktasıdır.

\section{Yöntem}

Çalışmada bisiklet yolunun kent için ulaşım sistemlerine entegrasyonunda uygulanan fiziksel ölçütlerin belirlenirken izlenen tasarım sürecine yer verilmiştir. Çalışma yöntemi kuramsal çerçeve oluşturulurken izlenen yöntem ve uygulamanın olumlu ve olumsuz yönleri tespit edilirken izlenecek yöntem olarak iki aşamada kurgulanmıştır. Çalışmanın kuramsal çerçevesini oluşturan bu süreç gözlemlenirken çeşitli tasarım kılavuzları üzerinde analiz yöntemi tekniği kullanılmıştır. Çalışmanın uygulama alanı için seçilen yöntem ise, South Park Street üzerinde yer alan çalışma alanında yerinde ölçüm yöntemi ve fotoğrafla tespit yöntemi kullanılmıştır. Tasarımda uygulanmış olan fiziksel ölçütlerin güçlü ve zayıf yönlerinin tespiti için yerinde gözlem yöntemi kullanılmıştır.

\section{Örneklem Alanı}

Çalışma alanı olarak Halifax kenti seçilmiştir. Kent nüfusu yaklaşık 415.000 kişidir. 5.490,28 km² yüzölçümü ile İstanbul'un yüzölçümünden büyük bir kenttir. Kent Atlantik okyanusu kıyı şeridinde yer almaktadır. Halifax kenti bisiklet yol ağına Şekil 1'de yer verilmiştir. Çalışma bölgesi, South Park Street olarak belirlenmiştir. 


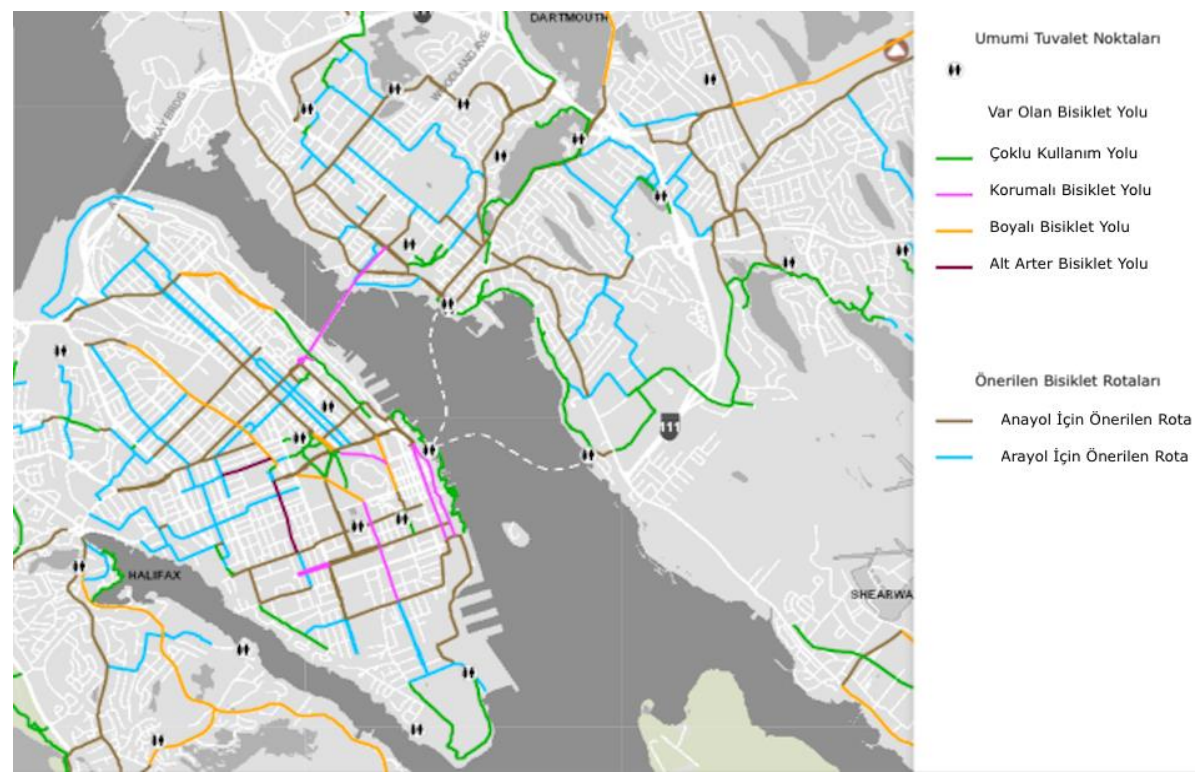

Şekil 1. Halifax Kenti Bisiklet Yolları Haritası (Halifax Bike Map, 2021)

\section{Bulgular}

Bisiklet yollarının oluşturulmasında, öncelikli rotaların belirlenmesi için Belediyenin hazırlamış olduğu katılımcı çalışmanın önemiyle beraber, motorlu araç yollarına bisiklet yollarının eklenmesi problemi için, yolların motorlu araç sürücüleri ve bisikletçiler tarafından güvenli bir şeklide paylaşılarak kullanılması ve çeşitli trafik kuralları ile kamusal mekânda fiziksel standartların uygulanması önem taşımaktadır. Bu doğrultuda tasarım için önemli veri sağlayan bisiklet yolu çeşitleri kuramsal çerçeve içerisinde anlatılmıştır.

\section{Kuramsal Çerçeve}

Halifax belediyesinin bisiklet yolunun kent içi ulaşımına entegre edilmesi için öncelikli yapmış olduğu analizlerin, mevcut sokağın/caddenin trafik yoğunluğunu tespit etmek, maksimum araç hızını belirlemek ve transit araç hacmini hesaplamak ve mevcut sokak/caddenin fiziksel üst ve alt yapı durumunu analiz etmek olduğu görülmüştür. Bu doğrultuda entegre edilecek bisiklet yolu için, bisiklet şeridi tasarımına yön verilmiş olmaktadır. Bu amaçla 91 Kuzey Amerika kentinin üye olduğu birlik olan NACTO/National Association of City Transportation Officials, bisiklet yolları için bir rehber hazırlamıştır. Tablo 1'de rehberde yer alan bazı bisiklet yolu çeşitleri, kullanıldığı yerler ve olumlu yönlerine yer verilmiştir. 
Tablo 1. Bisiklet Şeridi Tasarım Şekilleri (NACTO/National Association of City Transportation Officials, 2021)

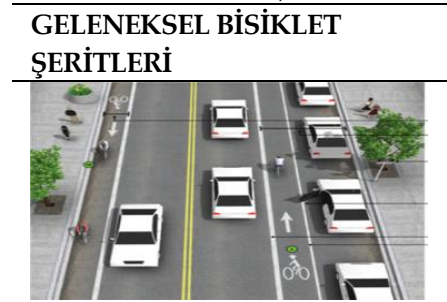

TANIM: Kaldırım işaretleri ve tabelaların kullanımıla özel bir alan belirler. Motorlu taşıtların seyir şeritlerinin bitişiğinde yer alır. Motorlu taşıt trafiğiyle aynı yönde akar. Genel olarak sokağın sağ tarafında, taşıt şeridine bitişik ve kaldırım, yol kenarı veya park şeridi arasinda bulunur.

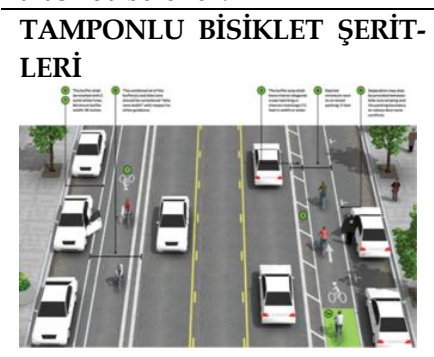

TANIM: Bisiklet şeridine bitişik motorlu taşıt seyahat şeridinden ve/veya park şeridinden ayıran belirlenmiş bir tampon boşlukla ayırılmış geleneksel bisiklet şeritleridir.

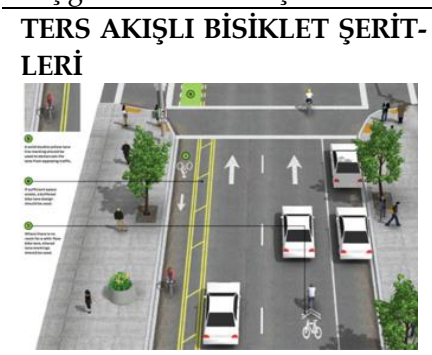

TANIM: Bisikletlinin motorlu taşıt trafiğinin ters yönünde sürmesine izin vermek için tasarlanmış alanlardır. Tek yönlü bir caddeyi iki yönlü bir caddeye dönüştürürler. Bir yön motorlu taşıtlar ve bisikletler için, diğeri sadece bisikletler

\section{UYGULANDIĞI OLUMLU ÖZELLIKLER YERLER}

*Bisiklet şeritleri, günlük ${ }^{*}$ Kalabalık caddelerde sürücü ortalama $\geq 3.000$ motorlu konforunu ve güvenini artırır. araç trafiğinin olduğu *Bisikletliler ve otomobiller cadde için uygulanabilir. arasında ayrım yaratır.

* Bisiklet şeritleri en çok, *Bisikletli ve sürücü konumbelirtilen hızın $\geq 25$ mil ol- landırma ve etkileşiminin önduğu sokak için uygulana- görülebilirliğini artırır.

bilir.

* Transit araç hacminin yüksek olduğu caddeler için uygundur.

*Bisiklet ve motorlu taşıt trafiğinin karışık olduğu caddelerin toplam kapasitelerini art1rir.

*Sürücülere bisikletlilerin sokağa çımma hakkını görsel olarak hatırlatır.

*Yüksek seyir hızları, yüksek seyahat hacimleri ve/veya yüksek miktarda kamyon trafiği olan caddeler için uygundur.

* Ekstra şerit veya ekstra şerit genişliği olan sokaklar için uygundur.

* Bisiklet ve yaya etkileşimlerini yönetmek için toplu taşıma duraklarında dikkatli uygulanmalıdır.

*Alternatif bisiklet rotalarının aşırı yön dışı seyahat gerektirdiği yollarda,

*Trafiğin yoğun olduğu, güvenli olmayan caddelerde veya tampon ayırma gibi fiziksel koruma sağlanamıyorsa, düşük hiz ve düşük hacimli sokaklarda, *Karşı akış şeridinin, söz konusu cadde üzerindeki varış noktalarına doğrudan erişim sağladığı yollarda
${ }^{*}$ Motorlu taşıtlarla bisikletli arasında mesafe sağlar.

*Bisikletli için, motorlu araç seyahat şeridine girmeden, başka bir bisikleti geçmesi için alan sağlar.

*Park edilmiş arabalar ve bisiklet şeridi arasında bulunan tampon bölge ile, bisiklet sürücüsünü, taşıt kapı açılış bölgesinin dışinda tutarak korur.

*Bisiklet ağı kullanıcıları arasinda güvenlik algisina katkıda bulunarak bisiklet sürmeyi teşvik eder.

*Her iki yönde de seyahat eden bisikletlilere bağlantı ve erişim sağlar.

*Tehlikeli yanlış yönde sürüşü azaltır.

*Kaldırımda sürüşü azaltır.

*Bisiklet trafiğini sınırlamadan sürücülerin rota seçimini etkiler.

*Yön dışı seyahatleri ortadan kaldırarak bisikletliler için yolculuk mesafesini, karşılaşılan kavşak sayısını ve seyahat sürelerini azaltır. 
içindir. Trafik ters akış şeritleri, sarı orta şerit işareti ile ayrılır.
*Tek yönlü cadde de iki yönlü bisiklet geçişinin gerekli olduğu yerlerde.
*Bisikletlilerin daha güvenli, daha az trafiğe sahip sokakları kullanmasını sağlar.

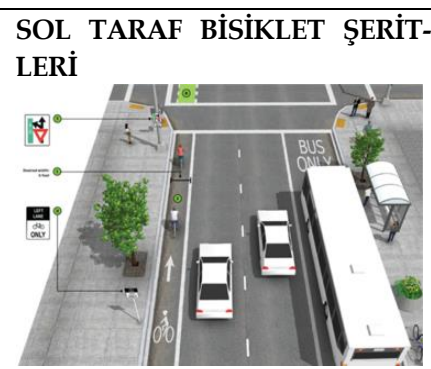

TANIM: Tek yönlü veya iki yönlü ortadan bölünmüş caddelerin sol tarafina yerleştirilen geleneksel bisiklet şeritleridir. Yoğun teslimat veya toplu taşıma kullanımı, sağ tarafta sık sık park yeri değişimi veya sağ taraftaki bisiklet şeritleriyle ilişkilendirilebilecek diğer olası çakışmaların olduğu caddelerde avantajlar sunar.
*Caddenin sağ tarafinda kamyon yükleme bölgelerinin veya otobüs duraklarının sık olduğu ortadan bölünmüş caddelerde veya tek yönlü caddelerde.

*Araç park etme sıklığ1nın yüksek olduğu caddelerde.

*Yoğun saatlerde park k1sitlaması olan sokaklarda. *Motorlu araçların sağa dönüş hareketlerinin yüksek olduğu caddelerde.

*Önemli sayıda sola dönen bisikletlinin bulunduğu caddelerde.
*Sokaklarda olası sağ taraftaki bisiklet şeridi çakışmalarını önler.

*Bisiklet şeridini sürücü tarafında tutarak sürücülerin görünürlüğünü iyileştirir.

*Sağ taraftaki seyahat şeritlerinin yoğun saatlerde park etme kısıtlamalarına ve diğer esnek kullanımlara tabi olduğu yerlerde tutarlı tesis konfigürasyonu sağlar.

*Araçların yolcu tarafinda daha az kapı açılması nedeniyle kapı bölgesi çakışmalarinı en aza indirir.

${ }^{*}$ Çoğu otobüs durağı ve yükleme alanı sokağın sağ tarafinda olduğundan daha az otobüs ve kamyon çakışması yaşanır.

Bu rehbere göre geleneksel, tamponlu, ters akışlı ve sol taraf bölge olarak dört farklı tasarım şekli kurgulanmıştır. Uygulanacak bölgedeki mevcut trafiğin ve yolun mevcut fiziksel özelliklerinin analiz sonuçlarına göre bu dört farklı bisiklet şeridi seçimi yapılabilmektedir. Bisiklet şeridi seçimine ek olarak alan için yapılması gereken bir diğer seçim ise bisiklet yollarının transit araç, küçük araç, diğer bisikletler ve yayalarla olan kesişim noktaları için Bisiklet Yolu Kesişim/Bağlantı tasarım şeklinin belirlenmesidir. Bu tasarım şekillerine Tablo 2'de yer verilmiştir. NACTO/National Association of City Transportation Officials bisiklet yolları için hazırlamış olduğu rehberde kesişim/bağlantı noktaları için yedi farklı tasarım çeşidi yer almaktadır. Tablo 2'de her bir tasarım şeklinin uygulanacağı yerlerin özellikleri ile tasarım şeklinin olumlu özelliklerine yer verilmiştir. Kesişim noktalarında uygulanacak tasarım şekillerinin, sinyalize olan ve olmayan kavşaklara göre, yüksek trafik hacmi ve hızının olduğu kavşaklara göre ve sağa ve/veya sola dönüşün olup olmama şartlarına göre tasarımlarında farklılaştı̆̆ görülmüştür. 
Tablo 2. Bisiklet Yolu Kesişim/Bağlantı Tasarım Şekilleri (NACTO/National Association of City Transportation Officials, 2021)

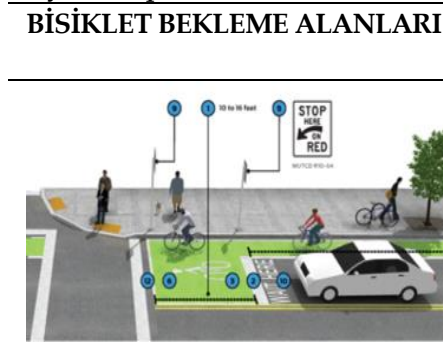

TANIM: Sinyalize bir kavşakta trafik şeridinin başında, bisikletlilere kırmızı sinyal aşamasında sıraya giren trafiğin önüne geçmek için güvenli ve görünür bir yol sağlayan, belirlenmiş bir alandır.

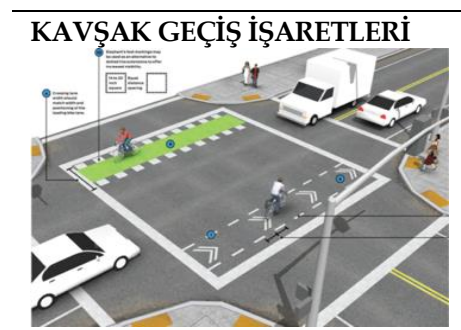

TANIM: Araç yolları ve kavşaklarda bisikletlilere güvenli ve doğrudan bir yol üzerinde rehberlik ederler. Bisikletlilerin yolları ile bitişik şeritteki motorlu araçlar arasinda net bir sinır sağlarlar.

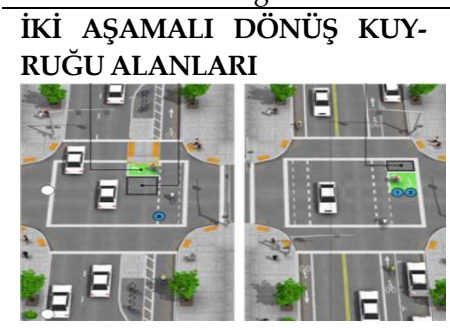

TANIM: Bisikletlilere çok şeritli sinyalize kavşaklarda sağ taraftaki bir bisiklet yolundan /şeridinden sola dönüşler yapmak veya sol taraftaki bir bisiklet yolu/şeridinden sağa dönüş yapmak için güvenli bir yol sunar.

\section{UYGULANDIĞI YER- OLUMLU ÖZELLIKLLER} LER

*Bisikletlilerin sik sola

ve/veya sağa dönüş yaptığı kavşaklarda.

*Bisikletliler ve araç sürücüleri arasında sağa/sola dönerken çakışma durumlarında.

*Belirlenmiş bisiklet rotasını takip etmek için sola dönüş gerektiğinde, ortak kullanımlı bir yola erişildiğinde veya bisiklet şeridi sokağın sol tarafina geçtiğinde.

*Sinyalize kavşaklarda, özellikle bisiklet yolunun belirsiz olabileceği geniş veya karmaşık kavşaklarda.

*Rampa trafiğinin hâkim hızının, sürücünün yol verme davranışının düşük olduğu rampa tarzı çıkışlar ve girişler gibi araç hareketlerinin sıklıkla bisiklet alanına girdiği yerler.

*Kırmızı sinyal göstergesi sırasında kavşaklarda bisikletlinin sola dönüş konumlandırmasını kolaylaştırır.

*Kırmızı sinyal göstergesi sırasında sağ taraftaki bisiklet şeridinden sol taraftaki bisiklet şeridine geçişi kolaylaştırır.

*Yayalar, yaya geçidine daha az araç girmesi ile güvenlik s1nurı artar.

*Bisikletlileri kavşak boyunca düz ve doğrudan bir yolda yönlendirir.

*Bisiklet bölgesini tanımlayarak bisikletçi stresini azaltır.

*Bisikletlilerin görünürlüğünü artırır.

*Bisikletliler ve dönüş yapan sürücüler arasındaki çatışmaları azaltır.

*Hem bisikletliler hem de sürücüler için potansiyel çatışma alanlarına yönelik farkındalık yaratır.

*Sinyalize kavşaklarda. ${ }^{*}$ Çok şeritli yollar boyunca.

*Yüksek trafik hızları ve/veya trafik hacimleri olan yollarda.

*Önemli sayıda bisikletçinin sağ taraftaki bir tesisten sola döndüğü yerlerde.

*Bisiklet parkurları boyunca.

*Tramvay raylarında güvenle gezinmek için
*Bisikletlinin güvenli ve rahat bir şekilde sola dönüş yapma yeteneğini geliştirir.

*İki aşamalı dönüş yapan bisikletliler için kuyruk alanı sağlar.

*Bisikletliler ve motorlu araçlar arasındaki dönüş çatışmalarını azaltır.

*Bisiklet şeridinde veya yaya geçidinde kuyruk oluşturan bisikletlilerden kaynaklanan çatışmaları önler.

*Dönen bisikletlileri diğer bisikletlilerden ayırır. 


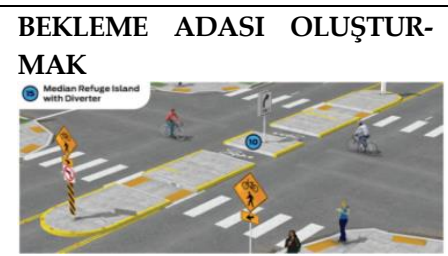

TANIM: Bisiklet ve yaya geçişlerini kolaylaştırmak için caddenin ortasına yerleştirilmiş korunan alanlardır. Bisikletlilerin ve yayaların ayn anda trafiğin yalnızca bir yönünde gezinmesine izin verilerek iki yönlü caddelerin geçişleri kolaylaştırırlar.

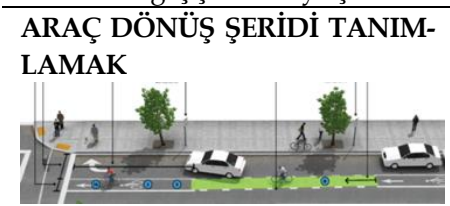

TANIM: Bisikletli için geleneksel bisiklet şeridinden bir kavşağa yaklaşmak zorluk yaratabilir. Bu uygulama, kendilerini doğru konumlandırma firsatı sağlar.

\section{BİRLEŞIKK BİSIKLET ŞERIDİ VE DÖNÜŞ ŞERIDI}
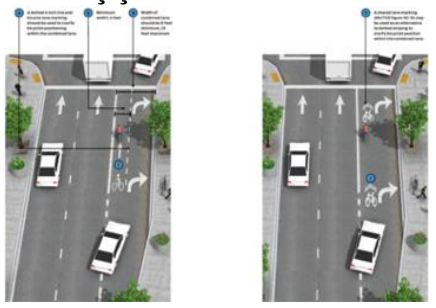

TANIM: Ortak şerit işaretleri veya kesik çizgili geleneksel bisiklet şablonları, bisikletliler ve sürücüler için paylaşılan şerit içindeki alanı tanımlayabilir veya bisikletliler için amaçlanan yolu gösterebilir.

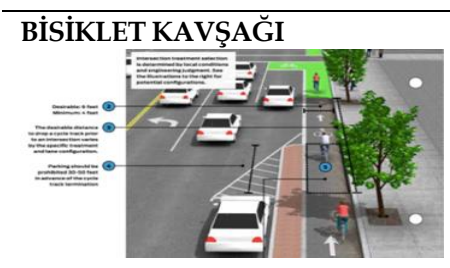

*Bir bisiklet yolunun orta yüksek hızlı bir caddeyi geçtiği yerlerde uygulanir.

*Bisiklet ve yaya yoğunluğunun yüksek olduğu caddeler boyunca.

*Sinyalize veya sinyalsiz kavşaklarda.

*Aracin hareketler yoluyla sinirlandırılmasının istendiği durumlarda.

\section{*Sağ bisiklet şeritleri olan sokaklarda sadece sağa dönüş kavşaklarında. \\ *Sol bisiklet şeritleri olan sokaklarda sadece sola dönüş kavşaklarında

\footnotetext{
*Bisikletlilerin kendilerini sağa dönüş şeritlerinin soluna veya sola dönüş şeritlerinin sağına doğru konumlandırmalarını sağlar

*Sürücüler ve bisiklet arasında çakışmaları azaltır.

*Bisikletlilere seyahat yolunu izlemeleri için rehberlik sağlar.
}

*Yolu fiziksel olarak daraltarak bir caddedeki trafiği sakinleştirir ve motorlu taşıtların sola dönüş hareketlerini potansiyel olarak kısitlar.

*Bir bisikletli veya yaya için toplam geçiş uzunluğunu ve araç trafiğine maruz kalmayı azaltır.

*Bir bisikletçinin karşıdan karşıya geçmek için yaşayacağı gecikme miktarını azaltır. ila yüksek hacimli veya

*Sağa dönüşşeridinin olduğu ancak kavşakta standart genişlikte yeterli alanın olmadığı sokaklarda.

*Sağa dönüş şeridinin olmadığı ancak yüksek hacimli sağa dönüsş trafiğinin sürücüler ve bisikletliler arasında çakışmalara neden olabileceği sokaklarda.

*Bisiklet yolu ile cadde tarafında özel bir dönüş şeridinin bulunduğu ancak bisiklet sinyalinin uygulanabilir olmadığı alanlar için uygundur.

*Bisiklet yollarının, bisikletçinin yolu boyunca (sol veya sağ) dönüş hareketlerine izin verildiği kavşaklara yaklaştı̆̆ yerlerde.
*Bisikletlilere, bitişikteki şeritten daha düşük hızlı trafiğe sahip olma eğiliminde olan dönüşş şeridinin bir kısmında sürmeleri için rehberlik eder ve trafikten daha yüksek hızın engellenmeden geçmesine izin verir.

*Sürücüleri, dar sağa dönüş şeridinden geçerken bisikletlilere yol vermeye teşvik eder. * Sağ dönüşs şeridinde motorlu araç hızını azaltır.
*Kavşaktan önce bisikletlilerin ve sürücülerin görünürlüğünü artırrr.

*Dönen sürücülerle çarpma riskini azaltır.

*Bisiklet sinyallerini kullanmaktan daha ucuz olabilir. 
TANIM:Korumalı bisiklet yolu bariyerinin kaldırılması, yükseltilen bisiklet yolunun sokak seviyesine indirilmesi ve bisiklet şeridinin, bitişik motorlu araç şeridine yakın olarak düzenlenmesi ile oluşan bağlantı türüdür.
*Motorlu araçlar için ayrilmış tek bir sağa dönüş şeridi olan kavşaklarda.

*Araç parklarının korun-

duğu sokaklarda.

Uygulanacak bisiklet yolu ve bağlantı/kesişim noktası tasarım biçimine göre yol üzerine eklenen işaretlerde değişkenlik göstermektedir. Bu nedenle bisiklet yolu için bisikletlinin, yayanın ve diğer araçların uymaları gereken bazı kurallar trafik işaretleri düzenlenmiştir. Bu işaretler güvenli sürüş için yayalar ve sürücüleri korumaktadır.

Tablo 3'de Halifax'ın da üye olduğu Ulusal Şehir Ulaştırma Birliği (NACTO) tarafından hazırlanmış olan bisiklet yolu trafik işaretleri ve anlamlarına yer verilmektedir.

Tablo 3. Halifax Kent İçi Bisiklet Yolu Trafik İşaretlerinin Anlamı (NACTO/National Association of City Transportation Officials, 2021)

\begin{tabular}{|c|c|c|c|}
\hline İşaretler & Anlamı & İşaretler & Anlamı \\
\hline & $\begin{array}{l}\text { Bisiklet Rota İşareti } \\
\text { Bir bisiklet rotasının parçası } \\
\text { olan yolu belirtir }\end{array}$ & & $\begin{array}{l}\text { Ayrılmış bisiklet Yolu } \\
\text { Bisiklete binen kişilerin özel kulla- } \\
\text { nımı için ayrılmış bir şeriti belirler. } \\
\text { Park etmeye izin verilmez }\end{array}$ \\
\hline & $\begin{array}{l}\text { Paylaşımlı Şerit İşareti } \\
\text { Araba süren ve bisiklete binen } \\
\text { kişiler için ortak bir şeridi belir- } \\
\text { tir. İşaretleme aynı zamanda } \\
\text { bisiklete binen insanlara bisik- } \\
\text { letlerini caddede nereye yer- } \\
\text { leştireceklerini göstermek için- } \\
\text { dir. }\end{array}$ & & $\begin{array}{l}\text { Sola Dönüş İşareti } \\
\text { Bisikletlilerin sağ bisiklet şeridinden } \\
\text { sola dönmelerini sağlamak için kulla- } \\
\text { nulır. Kullanıcılar yeşil ışıklı bir kav- } \\
\text { şaktan geçecek ve diğer yönde bek- } \\
\text { leme alanına girecekler. Işık değişti- } \\
\text { ğinde, yeni yönde seyahat edebilirler. }\end{array}$ \\
\hline & $\begin{array}{l}\text { Bisikletli Hariç Kısıtlı Hare- } \\
\text { ket: Sürücülere ve bisikletlilere } \\
\text { sola, sağa dönemedikleri, kav- } \\
\text { şaktan dümdüz geçemedikle- } \\
\text { rini söylemek için kullanılır. } \\
\text { Bu işaret bisikletlerin kısıtla- } \\
\text { madan muaf olduğunu ifade } \\
\text { eder. }\end{array}$ & & $\begin{array}{l}\text { Bisikletlerin Yaya olarak Hareket } \\
\text { Ettiği Alanlar } \\
\text { Bisikletlilerin yaya olarak geçtiği } \\
\text { veya bir tesisi paylaştı̆̆ ve yayalara } \\
\text { yol vermeleri gereken yerlerde kulla- } \\
\text { nılır, örn. bisiklet şeritli otobüs du- } \\
\text { raklarından önce. }\end{array}$ \\
\hline \begin{tabular}{|l} 
SHARE \\
THE ROA
\end{tabular} & $\begin{array}{l}\text { Paylaşımlı Yol } \\
\text { Bu işaretler genellikle Hali- } \\
\text { fax'ta bir bisiklet şeridinin bit- } \\
\text { tiği veya yolların zayıf görüş } \\
\text { veya dar şeritler gibi potansi- }\end{array}$ & $\begin{array}{l}\text { SINGLE } \\
\text { FILE }\end{array}$ & $\begin{array}{l}\text { Ortak Kullanılan Şerit İşareti } \\
\text { Sürücülerin şeridin yan yana seyahat } \\
\text { için çok dar olduğu konusunda uyar- } \\
\text { mak için kullanılır. }\end{array}$ \\
\hline
\end{tabular}


yel olarak güvenli olmayan koşullar sunduğu yerlerde kullanulır.

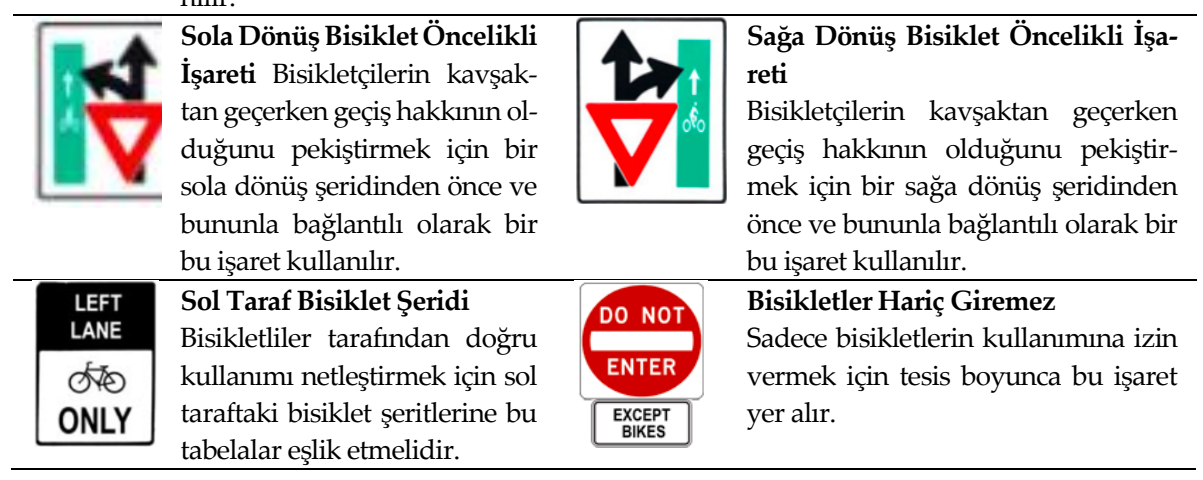

Bisiklet şeridi tasarım şekilleri, bisiklet yolu kesişim/bağlantı tasarım şekilleri ve Halifax kent içinde kullanılan bisiklet yolu trafik işaretlerinin anlamı kuramsal olarak değerlendirildikten sonra, ikinci bölümde Halifax belediyesinin, bisiklet yollarının kent içi ulaşımına entegrasyonu için planlama ve tasarım sürecinde almış oldukları bazı kararlar ele alınmaktadır.

\section{Halifax Belediyesi'nin Bisiklet Yolları Uygulanması için Planlama ve Tasarm Süreci}

Oluşturulmuş yeni bisiklet yollarının yenilenmesi ve sürekliliğinin sağlanması için planlama sürecini kronolojik sırayla ele aldığımızda Tablo 4'de belirtilen temel kararların uygulanmış olduğu görülmüştür. 
Tablo 4. Halifax Belediyesi Planlama Sürecinde Almış Olduğu Temel Kararlar

\begin{tabular}{ll}
\hline & Nisan 2016:Projenin, gelişmiş potansiyel seçeneklerini konuşmak \\
tartışmak için ilk açık toplantı düzenlenmiştir. \\
Ocak ve Şubat 2017: Halk katılımı oturumları düzenlenerek ve \\
bisiklete binen insanlar için konfor ve güvenlik düzeyi ve \\
önerilen rota boyunca park etme üzerindeki etki dahil olmak \\
üzere önerilen seçenekler hakkında geri bildirim toplamak için \\
Şehrinizi Şekillendir isimli bir anket yayınlanmıştır. \\
PLANLAMA \\
SÜRECI \\
$\begin{array}{ll}\text { Aralık 2017:Bölgesel Konsey, South Park Street'i Bölgesel } \\
\text { Merkez AAA Bisiklet Ağ1 içinde bir bağlantı olarak tanımlayan }\end{array}$ \\
Entegre Hareketlilik Planını kabul eder. \\
Mart 2018:Bölgesel Konsey, South Park Caddesi için korunan bir \\
sokak bisikleti tesisinin uygulanmasını rapor onaylanmıştır. Bu \\
raporda mevcut 1.2 km uzunluktaki yolun genişlikleri ile ilgili \\
alınmış olan kararlara ait plan ve kesit bilgilerine yer verilmiştir \\
(Şekil 2). \\
$\begin{array}{l}\text { 2019 ve 2020 yıllarında bu cadde iki farklı yapım bölgesine } \\
\text { ayırılarak uygulaması tamamlandı. }\end{array}$
\end{tabular}

Bisiklet yollarında önerilen değişikliklerin potansiyel etkilerini anlamak için Halifax belediyesi (Halifax Regional Municipality) ve WSP (Yapılı ve doğal çevrede yönetim ve danışmanlık hizmetleri sunan Kanadalı bir şirkettir) tarafından çeşitli analizler yapılmıştır. Bunlar;

- Bisiklet yolları oluşturulurken tasarım şekillerinin belirlenmesi,

- Seçilecek tasarım için değerlendirme kriterlerinin oluşturulması,

- Seçilen tasarımın mevcut yola entegrasyonu sonrası yol kenarı otopark alanlarının analiz edilmesi,

- Seçilen tasarımin mevcut yola entegrasyonu sonrası engelli otopark alanlarının analizi,

- Seçilen tasarımın mevcut yola entegrasyonu sonrasi taksi durak/bekleme alanlarının analizi başlıklarını kapsamaktadır.

Tablo 5. South Park Caddesi Kent İçerisindeki Konumu ile Çalışma Alanının Bisiklet Yolu Entegrasyonu Önce ve Sonrası Yol Genişlik Kesiti 


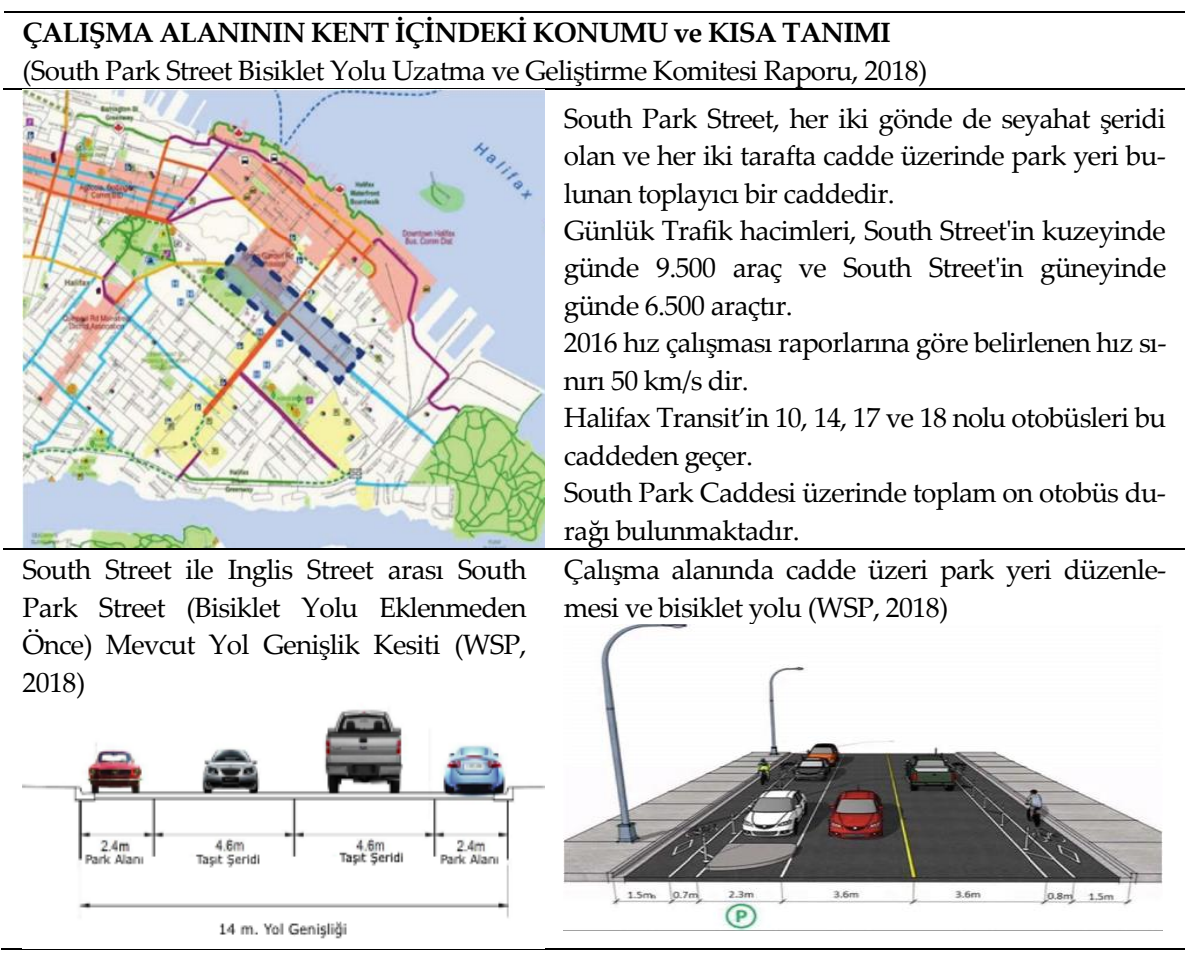

Mevcut taşıt sistemine yeni bir bisiklet yollunun entegre edilebilmesi için, tasarım yapılacak bölgede çok yönlü bağlamsal analizlerin yapılması, planlama modellerinin geliştirilmesi gerekmektedir. Bağlam, yapılan tasarımın, içinde yer aldığı ortamla ilişkilidir. Bu kavram, tasarım yapılacak bölgenin kent içindeki konum ve çevre özelliklerini, kimliğini, gelişimini anlamak için tanımlanmıştır. Bu doğrultuda bağlam ve analizler, toplum yapısından, bölgesel kimlik ve yerel karaktere, detay analizlerden sürdürülebilirliğe kadar geniş bir yelpazeyi içerir. Bu çalışmada Halifax belediyesi tarafından yapılan bağlamsal analizin, kullanıcı alışkanlıkları ve taleplerini de kapsayacak şekilde, tasarım, bağlantılar, uygulanabilirlik ve bölgeden sağlanacak kamu ve paydaş desteği kriterleri çerçevesinde, kentin yereline özgü olarak değerlendirildiği görülmüştür. WSP' nin hazırladığı ve analizlerini yaptığı üç tasarım seçeneği ile mevcut durum, değerlendirme kriterleri doğrultusunda karşılaştırmalı olarak değerlendirilmiştir. Analiz sonuçlarına göre en çok istenen ve en uygulanabilir seçenek tercih edilmiştir. Bu tercihin yapılmasında etkin rol oynayan kriterlere Tablo $6^{\prime}$ da yer verilmiştir. 
Tablo 6. Bisiklet Tesisi Seçimi İçin Değerlendirme Kriterleri Tablosu (WSP Raporundan Alınarak Oluşturulmuştur.WSP,2018)

\begin{tabular}{|c|c|c|c|c|}
\hline DEĞERLENDIRME KRITERLERİ & \multicolumn{4}{|c|}{ BİSIKKLET TESİSI SEÇENEKLERİ } \\
\hline En beğenilen & \multirow{3}{*}{$\begin{array}{l}\text { Mevcut } \\
\text { Durum }\end{array}$} & \multirow{3}{*}{$\begin{array}{l}\text { Tamponlu } \\
\text { Bisiklet Yol- } \\
\text { ları }\end{array}$} & \multirow{3}{*}{$\begin{array}{l}\text { Korumalı } \\
\text { Bisiklet } \\
\text { Yolları }\end{array}$} & \multirow{3}{*}{$\begin{array}{l}\text { Sokak } \\
\text { Üzerinde } \\
\text { Olmayan } \\
\text { B.Yolları }\end{array}$} \\
\hline$\longrightarrow$ & & & & \\
\hline En az beğenilen & & & & \\
\hline \multicolumn{5}{|l|}{ 1.EN İYI TASARIM } \\
\hline \multicolumn{5}{|l|}{ Sürüş Güvenlik ve Konfor } \\
\hline \multicolumn{5}{|l|}{ Kavşak Güvenlik ve Konforu } \\
\hline \multicolumn{5}{|l|}{ Otobüs Güvenlik ve Konforu } \\
\hline \multicolumn{5}{|l|}{ 2.BAĞLANTI } \\
\hline \multicolumn{5}{|l|}{ Diğer Bisiklet Ağına Bağlantı } \\
\hline \multicolumn{5}{|l|}{ Inglis Street'e Devam Etmesi } \\
\hline \multicolumn{5}{|l|}{ 3.UYGULAMALAR } \\
\hline \multicolumn{5}{|l|}{ Yayaya Etkisi } \\
\hline \multicolumn{5}{|l|}{ Otobüslere Etkisi } \\
\hline \multicolumn{5}{|l|}{ Motorlu Taşıtlara Etkisi } \\
\hline \multicolumn{5}{|l|}{ Ticari/Konut Otoparkına Etkisi } \\
\hline \multicolumn{5}{|l|}{ Erişilebilir Park Alanına Etkisi } \\
\hline \multicolumn{5}{|l|}{ Taksi Durağına Etkisi } \\
\hline \multicolumn{5}{|l|}{ Yeşil Alana Etkisi } \\
\hline \multicolumn{5}{|l|}{ Bakım } \\
\hline \multicolumn{5}{|l|}{ Sermaye Maliyeti } \\
\hline \multicolumn{5}{|l|}{ 4.DESTEK } \\
\hline Genel Kamu/Paydaş Desteği Seviyesi & & & & \\
\hline
\end{tabular}

Seçeneklerin değerlendirme matrisi Ulaştırma Komitesi Raporu, WSP kaynağından Türkçe' ye çevrilmiştir. Yeşil renk en cazip en uygulanabilir tasarımı, kırmızı renk ise en az beğenilen zor uygulanan tasarımı ifade etmektedir. Uygulama en beğenilenden en az beğenilen yeşilden kırmızıya değişen renklerle simgelenmiştir.

\section{Üç farkl tasarma göre bisiklet yolunun mevcut yola entegrasyonu sonrasi mevcut otopark alanlarnin analizi}

Çalışma Alanında, South Park Caddesi üzerinde mevcut durumda 450 cadde üzeri park yeri bulunmaktadır. Yeni hazırlanan alternatif üç bisiklet yolu tasarımına göre cadde üstü otopark durumunda yaşanacak değişimler değerlendirilmiştir (Tablo 7). 
Tablo 7. Üç Farklı Tasarıma Göre Yol Üstü Otopark Kayıpları (South Park Bicycle Lane Extension And Enhancement Council Report/WSP Global Inc.,2018)

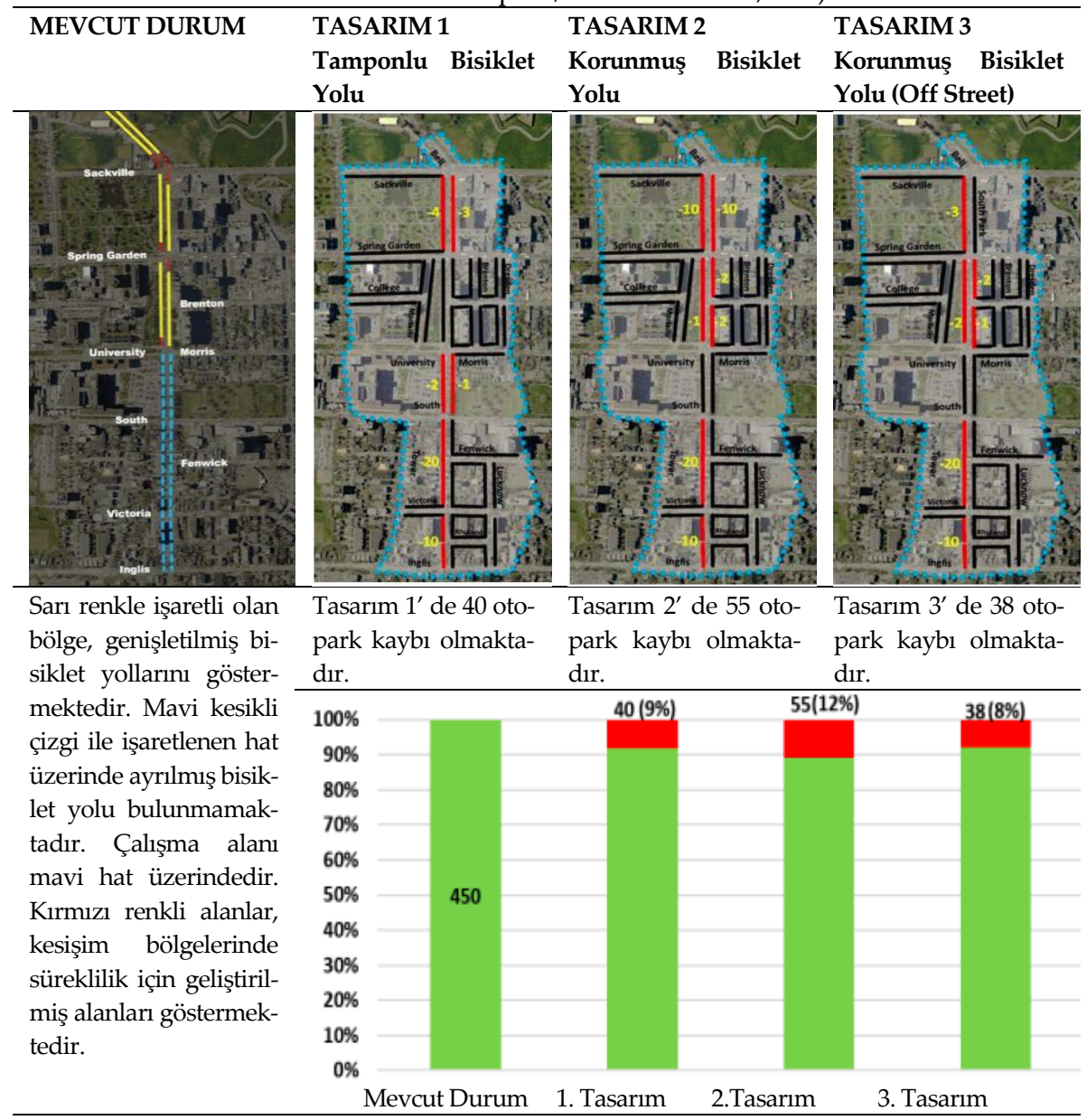

Bu sonuçlara göre en fazla 55 araç sayısı ile Tasarım 2' de otopark yeri kaybedilmektedir. En az ise 38 araç sayısı ile Tasarım 3'de kayıp yaşanmaktadır. Tablo 7'de üç tasarımın uygulanma halinde yol üstü otopark yeri sayısındaki kayıplara yer verilmiştir.

\section{Bisiklet yolunun mevcut yola entegrasyonu sonrası engelli otopark alanlarinin analizi}

Mevcut durumda South Park Caddesi'nde Sackville Caddesi ile Inglis Caddesi arasında 4 adet erişilebilir park yeri bulunmaktadır. Uygulanacak tasarımla birlikte, bir tane erişilebilir park alanının değişmesi gerekmektedir. Bu uygulamada yüzer park şeridi şeklinde uygulanacağı için, tüm erişilebilir park alanları yeniden yapılandırmayı gerektirmiştir. Bisiklet şeridi boyunca 
erişilebilir alanlardan kaldırıma güvenli erişimi kolaylaştırmak için Şekil 2'deki tasarım uygulanmıştır.

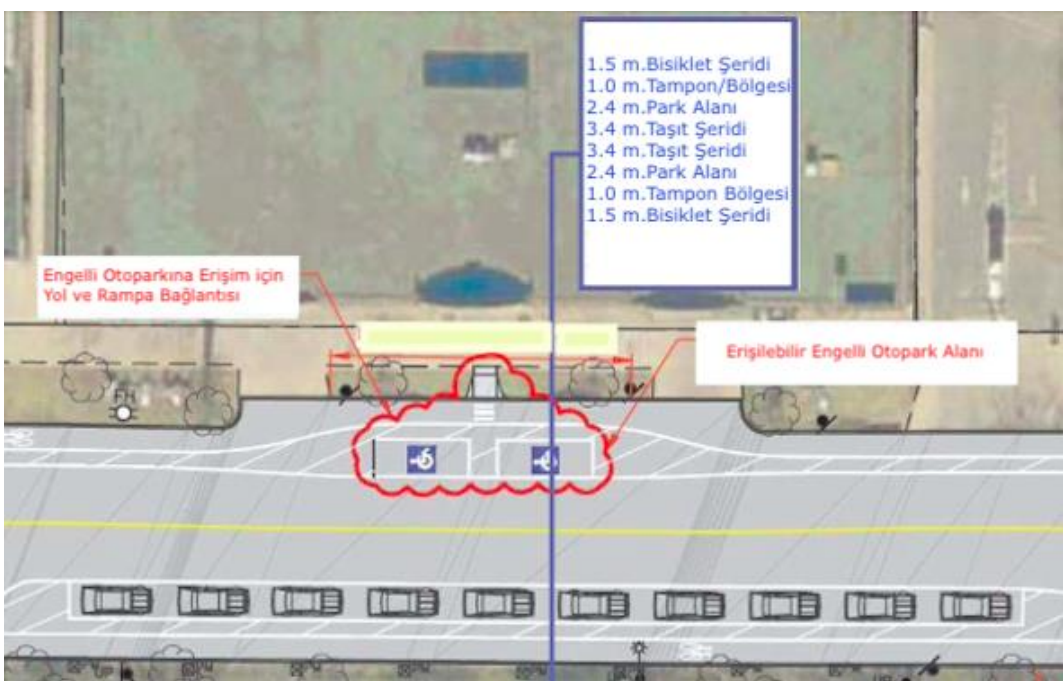

Şekil 2. South Park Caddesi Üzerinde Uygulanan Yüzer Engelsiz Park Alanı (South Park Bicycle Lane Extension And Enhancement Council Report/WSP Global Inc.)

\section{Bisiklet yolunun mevcut yola entegrasyonu sonrasi taksi durak alanlarmin analizi}

South Park Bisiklet Yolu Uzatma ve Geliştirme Konseyi Raporuna göre,

korumalı bisiklet şeridi seçeneğinin uygulanması sonrası 4 araçlık taksi durağı için yeni konum belirlenmesi gerekliliği belirtilmiştir. Bu yaklaşım ile;

1. South Park Caddesi'nin batı tarafında taksi durağının mevcut konumunun kuzeyi,

2. Smitty restoranın karşısındaki katedral yolu

3. Smitty restoranın önündeki katedral yolu

4. 1464 Katedral yolu girişinin önünde

5. Spring Garden Road, Smitty restoranının önünde doğuya doğru olmak üzere beş alternatifli taksi durağı konumu belirlenmiştir.

Taksi durağının yeniden yerleşimi için taksi ve limuzin irtibat grubu ile iletişime geçilmiştir (Halifax Regional and Transportation Standing Council, 2018). Sonuç olarak hat boyunca yer alan üç taksi durağının mevcut konumlarında kalabileceği ancak bisiklet şeridi ile trafik şeritleri arasındaki yüzer park şeridine geçecek şekilde yeniden yapılandırılacağı sonucuna varılmıştır. 


\section{Seçilen Tasarımın Uygulanması Sonrası Çalışma Alanına Ait Tespitler}

Çalışma ya konu olan bölge, Halifax kent içi bisiklet ağının bir parçasıdır. South Park Caddesi'nin South Street'den Inglis Street'e kadar yer alan her iki tarafında tek yönlü korumalı bisiklet yollarını içermektedir. İyileştirilmiş bisiklet şeritleri ile iki aşamalı dönüş bekleme alanları ve bisiklete binen insanlar ile motorlu araç trafiği arasında fiziksel bir ayrım oluşturmaktadır. South Street'ten Inglis Street'e kadar eskiden varolan kısa süreli ödemeli araç park yerleri, bisiklet yollarının batı komşuluğuna alınarak, caddenin sadece doğu tarafında uygulanmıştır.Bu hat caddenin solunda ve sağında olmak üzere bisikletliler için gidiş ve geliş sağlamaktadır.

Bu sürüş rotası, planlanan şekliyle ilerlenen zamanlarda University Avenue, Morris Street ve Bell Road'daki bisiklet şeritlerine bağlanarak diğer planlanmış bisiklet koridorlarına geçişi sürekli kılacaktır. Bisiklet şeritlerinin toplu taşıma duraklarıyla kesiştiği yerlerde, bisiklet şeridini kaldırım yüksekliğine getirmek için bir rampa kullanılmıştır. Kaldırım yüksekliğinde ortak bir bisiklet şeridi transit platformu oluşturulmuş ve görme bozukluğu olan kişilerin bisiklet şeridini geçtiklerinin farkında olmalarını sağlamak için dokunsal uyarı iz göstergeleri uygulanmıştır.

Bisiklete binen insanları yavaşlamaları ve otobüse binen ve otobüsten inen insanlara yol vermeleri konusunda uyarmak için kaldırım işaretleri ve tabelalar düzenlenmiştir. Bu işaretlere uyulması sürüş konforu ve güvenliğini artırmaktadır.

Bu proje sonucunda South Park Caddesi'ndeki park yerlerinin sayısında ve konumunda değişiklikler meydana gelmiştir. Alanın izin verdiği yer ve durumlarda, park korumalı bisiklet şeritleri oluşturmak için mevcut park şeritleri kaldırımdan uzaklaştırılmıştır.

Spring Garden Road'dan South Street'e kadar caddenin her iki tarafında kısa süreli ücretli park yeri uygulaması devam etmektedir. Bu makalenin çalışma alanı olarak belirlenen South Street'ten Inglis Street'e kadar olan bölümde ise sadece caddenin doğu tarafında, cadde üzerinde ücretsiz. park yeri bulunmaktadır. Otoparkta yapılan diğer değişiklikler sonrasında cadde üzerinde otopark sayısı azalmıştır. Park sayısındaki kaybı azaltmak için bölgeye gelen ziyaretçiler için ara sokaklarda ek kısa süreli park etme (bazı bölgelerde $15 \mathrm{dk}$, bazı bölgelerde maksimum 2 saat olmak üzere) uygulamasına izin verilmiştir.

Bisiklet yolunda transit otobüs durak noktalarında, caddenin her iki tarafında yer alan bisiklet yolları kaldırım yüksekliğine yükseltilmiştir. Uygulanan tek yönlü bisiklet şeritleri, beton bordür ile araç trafiğinden ayrılarak korumalı duruma getirilmiştir. 
South Park caddesi üzerinde kesişim/bağlantı noktalarında geçiş mesafelerini azaltmak ve yaya güvenliğini artırmak için trafik sinyali ayarlamaları ve kavşak iyileştirmeleri yapılmıştır. Bisiklet yolu zeminde yer alan trafik işaretleri bisikletlilerin konforlu ve güvenli sürüşleri için önem taşımaktadır.

Mevcut motorlu taşıt yoluna bisiklet yolu eklenerek paylaşımlı yol biçimine ulaşan South Park Street caddesinden bazı fotoğraflara Tablo 8' de yer verilmiştir. Bu fotoğraflar üzerinde tasarım ölçütü olarak kullanılan korumalı bisiklet şerit biçimi, bisiklet yolu drenaj çözümü, bisiklet yolu aydınlatma elamanı, bisiklet yolu/motorlu taşıt yolu koruyucu beton bariyer, bisiklet yolu/yaya yolu kesişim noktası çözümü, trafik işaretleri, biriken kuru ağaç dal ve yapraklarının yoldan mekanik yöntemle uzaklaştırılması yer almaktadır.

Tablo 8. Bisiklet yolu çalışma alanına ait tespitler

KORUMALI BİSIKLET YOLU İÇİN TEMEL ALINAN ÖLÇÜTLER ve UYGULAMA SONRASI DURUM TESPITLERI

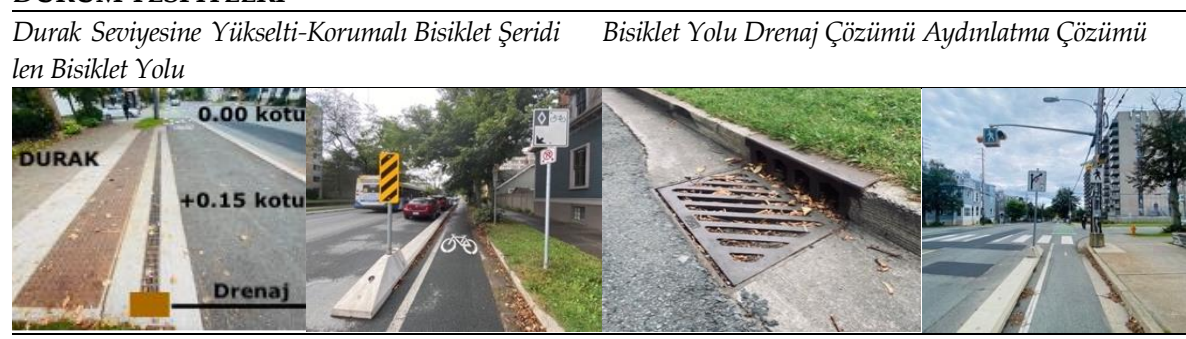

Bisiklet/Araç Yolu Kesişim Trafik İşaretlerinin Varlığ̆ Bölücü Eleman Çöpün Uzaklaştırılması

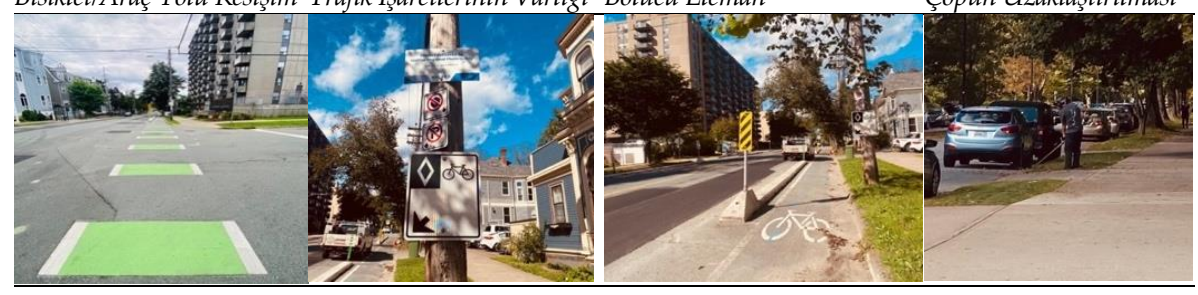

Bisiklet/Yaya Yolu Kesişim Otobüslerin Raf Sistemleri Araç Yolu Drenaj Çözümü Durak Entegrasyonu
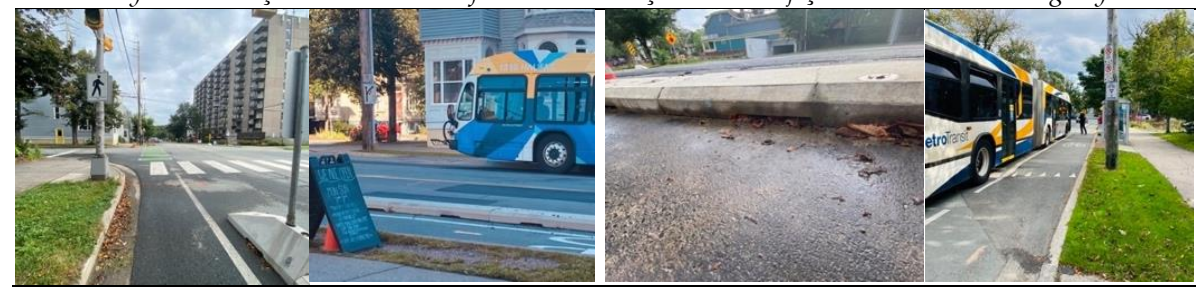


\section{Seçilen tasarımın uygulanması sonrası çalışma alanında oluşan problemler}

Bisiklet yolunun motorlu taşıt ulaşım sistemine eklenmesinde kullanılan ölçütlerin çalışma alanındaki durumlarının değerlendirilmesi ile ortaya çıkan problemlere Tablo 9'da yer verilmiştir.

Bu problemler arasinda;

- Bisiklet park istasyonlarınin bisiklet yollarından uzak mesafede bulunması ve bisiklet yolları komşuluğunda yer alan emniyet şeridi üzerindeki trafik işaret direklerine bisikletlerin park edilmiş olması,

- Bisiklet şerit genişliğinin bazı alanlarda, emniyet şeridi içerisinde yer alan peyzaj elemanlarından kaynaklı daralması,

- Bisiklet yollarının yaprağını döken ağaç türü komşuluğuna yapılmış olması nedeniyle kuru ağaç yaprak ve dallarının güvenli sürüş olanağını azaltması,

- Bisiklet yol şeridi içerisindeki kuru ya da kurmaya yüz tutmuş ağaç dal ve yapraklarının mevcut yağmursuyu drenaj ızgara kapaklarını tıkaması,

- Bisiklet şeritlerinin uygulanması ile motorlu araç yolunda şerit sayısinda azalma sonucu trafiğin yoğun olduğu saatlerde trafiğin tıkanması,

- Yaprağını döken ağaçlar için kaldırım ve bisiklet yollarının temizlenmesinde mekanik yöntemle uzaklaştırma yapılmaktadır. Bunun için mazotla çalışan bir alet kullanılmaktadır. Bu yöntemin uygulanması ile karbon salınımı yapması açısından çevreci bir yaklaşım olarak görülmemiştir. Ayrıca kullanılan alet çok fazla gürültü kirliliğine neden olmaktadır. Tablo 8 içerisinde çöpün uzaklaştırılması için çalışan personelin bu gürültüden etkilenmemesi için koruyucu kulaklık taktığ1 görülebilir.

- Motorlu araç yolu ve bisiklet şeridi arasında uygulanmış olan beton bordürün, araç yolları için yapılmış olan mevcut yağmur suyunun drenaja ulaşımını azaltmış ya da yer yer engellemiş olduğu tespit edilmiştir.

- Yapıların otoparklarına giriş/çıkış sağlanabilmesi için bisiklet yolu ile kesilen bölgelerde beton koruyucu bariyer kullanılmamaktadır. Aynı zamanda tekrar beton bariyerin başladığı noktada yol kenarı otoparkları bulunmaktadır. Yol kenarı otoparkına yaklaşan aracın, park 
ediş sırasında bu boşluk alanlardan (bisiklet yolu ve konut otoparkları kesişim noktası) geçen bisikletli için sürüş konfor güvenliği azalmaktadır.

- Bisiklet yollarının kesişim ve bağlantı yollarına yerleştirilen beton bitiş/başlangıç bariyerler üzerinde yer alan trafik levhasının yola sarkması ile sağa ve sola dönüş yapan transit otobüslerin yan aynalarının bu işaretlere çarptığı tespit edilmiştir. Trafik levhası ve koruyucu beton bitiş bariyerlerinin, asfalt yola sabitlenmesini sağlayan tij bağlantılarında, ayrılmaların meydana geldiği görülmüştür.

Bu problemlerin çözüm yolları için bazı öneriler geliştirilmiştir. Problemlerin çözüm önerisi olarak;

- Doğru yer analizi yapılmamasından kaynaklandığı düşünülmektedir. Kaldırım ile arasında yer alan emniyet şeridi üzerinde yer

- Emniyet şeridinden taşan peyzaj elemanları için düzenli kesme bak1mının yapılması ya da bitki köklerinin bisiklet yolundan uzaklaştırılmasi,

- Bisiklet yol şeridi içerisindeki kuru ya da kurmaya yüz tutmuş ağaç dal ve yapraklarının düzenli olarak toplanması,

- Bisiklet şeritlerinin uygulanması ile motorlu araç yolunun, trafiğin yoğun olduğu saatlerde tıkanmasının önlenmesi için kent harita uygulamasının anlık yol bildirimini ve durumunu göstererek yoğun trafiğin bulunduğu cadde ve sokakların kullanımının azaltılması,

- Her ne kadar motorlu araç ve bisiklet yol şeridi arasına uygulanan beton ayırıcı/koruyucu bordürün alt bölümünün belirli aralıklarda boşaltılarak, yağmur suyunun bu bölgeden akmasına olanak sağl1yor olsa da yeterli görülmemiştir. Bu nedenle yağmur suyu birikme noktaları gözlemlenip bu noktalarda yeniden drenaj ızgaraları motorlu araç yolu içerisinde uygulanmalıdır. Bir başka çözüm önerisi olarak, bisiklet şeridi içerisinde yer alan drenaj ızgaralarının sıklığının artırılabileceği öngörülmüştür.

- Bisikletlilerin güvenli sürüşlerini koruyucu beton bariyerlerin bulunmadığı alanlarda sürdürebilmeleri için yol kenarı otopark alanlarının beton bariyerin bitiş noktasındaki tek araçlık alana park yasağı koyularak çözülebileceği düşünülmüştür. Bu çözüm yol kenarı otopark sayısında azalmaya neden olacağı için çok boyutlu düşünülmesi gereken bir problem alanı olarak görülmüştür. 
- Koruyucu beton bitiş ve başlangıç bariyerlerinin üzerinde yer alan trafik levhalarının yola sarkmayacak şekilde, otobüs dönüş açısı hesaplanarak yeniden montajinın yapılması önerilmektedir. Bisiklet yolunun sokak/cadde kesişim alanlarında bulunan koruyucu beton bitiş/başlangıç bariyerlerinin mevcut bulunduğu noktadan 1 metre geriye çekilmesi de otobüslerin dönüş açısını düzenleme de yardımcı olacaktır.

Tablo 9. Uygulama sonrası bisiklet yollarında yaşanan problem

\begin{tabular}{|c|c|c|}
\hline \multicolumn{3}{|c|}{$\begin{array}{l}\text { BİSIKLET YOLUNUN ULAŞIM SİSTEMINE ENTEGRASYONU İÇİN UYGULANAN } \\
\text { TASARIMIN ÇALIŞMA ALANINDA YARATMIŞ OLDUĞU PROBLEMLER }\end{array}$} \\
\hline & $\begin{array}{l}\text { Bisiklet park istasyon } \\
\text { noktalarnnda yetersizliği } \\
\text { sonucu sürücü bisikle- } \\
\text { tini işaret ve uyarı levha } \\
\text { direklerine park etmekte- } \\
\text { dir. }\end{array}$ & $\begin{array}{l}\text { Uygulanan rampanın dre } \\
\text { naj ızara noktasına denk } \\
\text { gelmesi, yoğun yağıs za- } \\
\text { mantanda taşı yolunda } \\
\text { yağmur suyunun birikme- } \\
\text { sine neden olmaktadr. }\end{array}$ \\
\hline & $\begin{array}{l}\text { Çöplerin düzenli aralık- } \\
\text { larla uzaklaştırlmamış } \\
\text { olması, yağmur suyu } \\
\text { drenaj ızgaraların tıka- } \\
\text { maktadır. }\end{array}$ & $\begin{array}{l}\text { Bisiklet yolunun durak se- } \\
\text { viyesine yükseltilmesi için } \\
\text { uygulanan rampanın dre- } \\
\text { naj Izgarastn engelleme- } \\
\text { mekiçin dar tutulması, sü- } \\
\text { rücü için güvenlik sorunu } \\
\text { oluşturmaktadır. }\end{array}$ \\
\hline & \multicolumn{2}{|c|}{$\begin{array}{l}\text { Bisiklet yolu, mevcut araç yolunun beton bariyerle ayrlmast ile oluşturmuştur. Ta- } \\
\text { şıt yolu yağmur suyu drenaj ızgaraları bisiklet yolu içerisinde kalmıştır. Her ne ka- } \\
\text { dar bu sorun için beton bariyerin alt kısımlarında boşluklar bırakılmış olsa da, dökü- } \\
\text { len sonbahar yapraklarmın bu boşluğu doldurarak tıkanmalara neden olduğu görril- } \\
\text { müştür. Bu uygulama yoğun yağış esnasında taşıt yolunda su birikintilerine neden } \\
\text { olmaktadır. Taşıt yolu için birikintilerin olduğu alanlar için drenaj sisteminin yeni- } \\
\text { den kurgulanması gerekmektedir. }\end{array}$} \\
\hline & & $\begin{array}{l}\text { Bisiklet yolunun eklenmesi, taşıt yolunun daralmasına } \\
\text { neden olmuştur. Bu durum kavşak dönüşlerinde yolcu } \\
\text { otobüslerinin manevra kabiliyetini zayıflatmıştır. Oto- } \\
\text { büsün dönme esnasında yan aynalarnn levhaya, levha } \\
\text { direğine çarparak koruma bariyerinin zeminden ayrl- } \\
\text { masına ve levhanın zarar görmesine neden olmuştur. } \\
\text { Daralmalarn olduğu kavşak noktalarında, bisiklet yolu } \\
\text { dur çizgisinin, otobüs dur çizgisinden(beyaz kalın } \\
\text { çizgi) daha geride kurgulanması ya da birleşik dönü̧ş ş- } \\
\text { ridi uygulanması önerilmektedir. }\end{array}$ \\
\hline
\end{tabular}




\section{Tartışma ve Sonuç}

Sonuç olarak örneklem alanında bisiklet yollarının motorlu araç yoluna entegrasyonunda için fiziksel mekânda alınmış önlemler değerlendirildiğinde;

1. Bisikletlilerin ihtiyaçları gözetilerek ve katılım anket sonuçlarına göre öncelikle üniversite ve okullara erişilebilirliği en yüksek olduğu alanlarda ulaşım rotaları oluşturulmuştur.

2. Ana cadde üzerinde her iki şerit içinde bisiklet yolu oluşturulmuştur.

3. Bisiklet yolları özel imal edilmiş oluklu beton bordür taşı kullanılarak motoru araç yolundan fiziksel olarak ayrilmıştır.

4. Taşıt yolu bordür taşı ile fiziksel olarak ayrılmamış yollarda bisikletli, araç yolunun sağ tarafını kullanmaktadır. Bu yollarda araç ile bisikletli arasında, motorlu taşıt sürücülerinin uymaları için 1 metre mesafe kuralı getirilmiştir.

5. Kavşakların bisikletliler için daha güvenli hale getirilmesinde yol üzerinde yeterli mesafede yatay işaretlemeler ve uyarı levhaları kullanılmıştır.

6. Bisikletlilerin, otobüs duraklarındaki yolcularla çarpışmalarını önlemek ve otobüslere rahat erişebilmek amacıyla her iki kullanıcının ihtiyaçlarını karşılayan özel yol tasarımları uygulanmıştır (bisiklet yolu ile kaldırım arasındaki yükseklik seviye farkı rampa uygulaması arac1lı̆ıyla giderilmiştir).

7. Bisikletle ulaşım sistemi, otobüs ulaşım sistemine entegre edilerek (bisikletle binilen otobüslerin önüne takılan raf sistemleri sayesinde) varış noktasına ulaşmak için süreklilik sağlanmıştır.

8. Otobüs platforma yaklaştığında, bisiklet sürücüsü beyaz dur işaretinin arkasında durmak zorundadır. Yolcular otobüse binip indikten ve kapılarını kapattıktan sonra bisiklet sürüşüne devam edilebilir. Otobüsler durduklarında, taşıt rampaların bisiklet şeridine doğru açmaktadırlar.

9. Uygulanmış olan korumalı bisiklet şeridi seçeneği, South Park Street cadde üzeri park arzında değişikliklere neden olmuştur.

Bu çalışma ile, tasarım ve planlama ölçeğinde temel alınan kararlar ile uygulamanın olumlu ve olumsuz yönleri değerlendirilmiştir. Çalışma alanında bisiklet yolları oluşturulurken, meydana gelen problemlerin mevcut yapılı çevrenin altyapı ve üst yapı yeterliliğiyle ilgili olduğu ve bisiklet yollarını şekillendiren ölçütlerin bölgeye özgü planlama ve tasarım odaklı yaklaşımla çözülebildiği görülmüştür. 
Değerlendirme sonucunda Türkiye'de mevcut kent içi ulaşımına entegre edilecek bisiklet yolları için süreci yönetmede kullanılabilecek temel karar önerileri sunulmuştur. Bu doğrultuda Tablo 10'da önerileri içeren akış şemasina yer verilmiştir.

Tablo 10. Türkiye' de Mevcut Kent İçi Ulaşımına Entegre Edilecek Bisiklet Yollarının Oluşturulmasında Alınması Gereken Temel Karar Önerileri

1.Belediye bünyesinde bisiklet ile ulaşım için ayrı bir birim oluşturulmalıdır. Bu birim altında etüt ve planlama, yapım ve uygulama, bakım ve onarım birimleri kurgulanmalıdır. Ayrıca alanında uzman kişilerden oluşan bisiklet master plan komisyonu kurularak süreci kontrol ve organize eden bir yapı olmalıdır.

2. Mevcut yolların alt ve üst yapı envanterlerinin temin dilmesi, mevcut fiziksel durumla ilgili varsa eksikliklerin ilgili birimlerden talep edilerek giderilmesi sağlanmalıdır. Yapılan değişikliklerin mevcut durum güncellemesinin düzenli aralıklarla yapılması için bisiklet ile ulaşım biriminin yönerge hazırlaması gerekmektedir.

3. Halkın, kent bisiklet kulüpleri ile bisiklet sürücülerinin katılımını sağlayan bir organizasyon yapısı kurgulanmalı, yeterli katılım ile halkın talepleri ve potansiyel bisiklet kullanım alanları belirlenmelidir. Bu taleplerin anket aracllı̆̆ıla tespit edilmesi ve kayıt altına alınması önerilmektedir.

4. Alınan taleplere göre kent bölgelere/sokaklara/caddelere ayrılarak proje ve uygulamanın bölgesel bazda yapılması gerekmektedir.

5. Her bir bölge içerisinde yer alan cadde ve sokakların mevcut otobüs/taksi durakları, yol kenarı otopark alanları ile ticari/konut otopark alanları mevcut durum haritası üzerine işlenmeli, yapılan değişiklikler güncellenmelidir.

6.Sokak ve caddelerin trafik hacim, trafik hızı ve trafik yoğunlukları belirlenmelidir.

7. Sokak/cadde bağlantı ve kesişim noktaları tasarım şekilleri belirlenmelidir.

8.Sokak/caddelere ait mevcut şerit sayısı (tek yön/çift yön) ve şerit geçiş öncelikleri belirlenmelidir.

9. Sokak ve caddeler için belirlenen trafik hacim, trafik hızı, trafik yoğunlukları ve fiziksel standartlar doğrultusunda bisiklet tasarım şekilleri belirlenmelidir.

10. Sokak ve caddeler için belirlenen trafik hacim, trafik hızı, trafik yoğunlukları ve fiziksel standartlar doğrultusunda bisiklet yolunun türü belirlenmelidir.

11.Seçilen bisiklet yol çeşidiyle uyumlu olmak üzere yolların bağlantı/kesişim noktalarında uygulanacak tasarım şekilleri belirlenmelidir.

12. Otobüs duraklarına erişim, konut/ticari/kamu yapılarına erişim bağlantı güzergahlarının belirlenmesi gerekir.

13.Bisiklet yollarında bisikletli, yaya ve motorlu araçların uymaları zorunlu trafik ve zemin uyarıcı işaretlerinin koyulacağı nokta ve mesafelerin belirlenmesi gerekir.

14.Uygulama projesi hazırlanacak her bir etap için yapılması gerekenler listesi ve mevcut durum planları ilgili tüm birimlerden görüş alınarak komisyon tarafından raporlanması gerekmektedir. Bu rapor oluşturulduktan sonra projelerin hazırlanarak maliyet hesapları oluşturulmalıdır. 
15. Süreç, hem maliyet bazında hem de tasarım ve planlama odaklı olarak alternatif tasarım biçimleriyle değerlendirilerek yönetilmeli ve tasarım çeşitlerine göre ortaya çıan olumlu ve olumsuz etkiler üzerinde çalışılmalıdır. Bu sonuçlar oluşturulan yeni organizasyon birimine ve bisiklet master plan komisyonuna sunularak değerlendirilmelidir.

16.Planlama ve tasarım sürecinde alanında uzman kişi/firmalardan danışmanlık hizmeti alınarak sürecin sağlıklı ve doğru yönetilmesinin sağlanması için önemlidir.

17.Uygulama aşamasında ilgili fiziksel ölçüt ve standartların yerine getirildiğini kontrol eden bir mekanizmanın Belediye ve Çevre ve Şehircilik Bakanlığı bünyesinde oluşturularak çift kontrol mekanizması işletilmelidir.

18. Çevre ve Şehircilik Bakanlığı Bisiklet yolları kılavuzu esas alınarak, her belediyenin kendi çevresel özelliklerini dahil edeceği, kent bazlı bisiklet yolları master plan ve raporlarının, bisiklet master plan komisyonu tarafından yıllık olarak düzenli hazırlanması gerekmektedir.

19. Bisiklet master plan komisyonunun hazırlamış olacağı yıllık raporlar halkın ulaşabileceği bir platform olan belediye sayfalarında yer almalıdır.

20. Bisiklet ile ulaşımın olumlu özelliklerini içeren bilgilerin yer alacağı kamu spotları, broşürler vb. iletişim araçları kullanılarak halkın bilgilendirilmesi ve bisiklet kullanımının teşvik edilmesi Belediyeler tarafından sağlanmalıdır.

Bu önerilerle birlikte "Bisiklet bir ulaşım aracıdır, bisikletli ise taşıt sürücüsüdür" mottosunun özümsenmesi gerektiği ve trafik kurallarının bu yönde yeniden düzenlenmesi gerektiği önerilmektedir.

Bu çalışma ile, Halifax kenti özelinde uygulanan bisiklet yolu için, tasarım ve planlama sürecinin çok kapsamlı yönüne ve halkın katılımcı desteğini alan yerel belediyenin süreci yönetmesine dikkat çekmek istenmiştir. Ayrıca, trafik sıkışıklığının büyük sorun haline geldiği günümüz büyük şehirlerinde, bisiklet kullanımının alternatif bir ulaşım türü olması, ve pandemi sürecinde güvenli ulaşım olanağı sunması nedenleriyle konunun belediyeler tarafından çok kapsamlı ve çok disiplinli ele alınmasının önemi vurgulanmak istenmiştir. 


\title{
Extended Abstract
}

\section{Bicycle Route Design and Application Integrated in Urban Transportation: Sample of Cycle Paths in Canada/Halifax City}

\author{
* \\ Yelda Durgun Şahin \\ ORCID: 0000-0001-6708-9247
}

Bicycles are seen as a form of travel with many positive features such as making the transportation system of the 21st century green, reducing energy consumption and carbon emissions, leading a healthy life and supporting healthy transportation during the COVID 19 pandemic process. Creating a bicycle network in urban areas is an important aspect of promoting bicycle use as a means of transport.

The aim of the study has been determined as the examination of the decisions to be taken at the planning and design scale in the integration process of bicycle lanes, which are attached to urban transportation, through an applied sample project. As the study area, Canada-Nova Scotia Province, Halifax city, South Park Street area was chosen.

With this study, it is thought that an applied bicycle path will contribute to the literature in terms of evaluating the planning and design process and determining the positive and negative aspects of the design after the application. The studying method was designed in two stages as the method followed during the implementation of the theoretical framework and the method followed during the implementation phase. In the process that constitutes the theoretical framework of the study, analysis method technique was used on various design guides prepared by Halifax Municipality. The suitability of the selected bike lane design for the study area and the selection criteria were evaluated. The method chosen for the application area of the study consists of on-site measurement and photographic fixation methods. The positive and negative aspects of the application on the bicycle path on South Park Street have been determined. 
The study is structured in three parts. In the first part of the study, the design guides of Halifax municipality prepared for urban bicycle path applications were used and the design forms developed for bicycle paths integrated into urban transportation were included.

In the second part of the study, the decisions taken by the municipality of Halifax between 2016-2019, which is the planning and design process for the integration of bicycle paths into the city, are included. The bicycle path design applied for the selected sample area was examined in terms of the planning decisions taken before the application and the design process. Three proposals prepared for the study area were designed by the Standing Committee of Transport, safety and convenience of driving, safety and comfort at the intersection, safety and comfort of the bus, connection to the wider bicycle network, the continuation of the bicycle path to Inglis street, the pedestrian effect, the effect on the buses, The effect of motor vehicles, commercial and residential parking lot, accessible parking area, taxi stand, green space and urban forest, maintenance, cost of capital, general public/stakeholder support level evaluation criteria and their comparisons are included.

In the third part of the study, the strengths and weaknesses of the design were evaluated and analyzed by photographing, by making on-site determination studies after the application in South Park Street, which is the study area.

At the end of the study, it was considered positive to include the demands of the people while creating bicycle paths. Bicycle path designs, which have many different types, should be analyzed in all aspects of the application area and the most suitable type should be selected. Design criteria should be determined specifically for the study area and the criteria should be weighted by taking expert opinion. It has been seen that the characteristics of the area where the bicycle path will be applied are of great importance to create the design criteria.

In this study, the positive and negative aspects of the application were evaluated with the decisions taken at the design and planning scale. It has been seen that the problems that occur while creating bicycle paths in the study area are related to the infrastructure and superstructure adequacy of the existing built environment, and the criteria that shape the bicycle paths can be solved with a region-specific planning and design-oriented approach.

This study, which was examined as an example of Halifax urban transportation, was thought to be a guide for new bicycle routes to be integrated into urban transportation in Turkey. 
Creating a bicycle network in urban areas is an important aspect of promoting bicycle use as a means of transport. For this reason, it is necessary to create integrated mobility plans in line with a holistic approach within the entire movement system of cities and to develop design processes for bicycle transportation within this planning.

Construction of a protected bicycle lane on South Park Street to create an all-ages-and abilities cycling connection through downtown Halifax was completed in 2020. The project features bicycle lanes on each side of the street, with a wide buffer and concrete curb to separate bicycle traffic from parked cars and vehicles. The protected bicycle lane includes pre-cast concrete curb and flexible bollards to separate bicycle and vehicle traffic. It also includes asphalts material platforms at bus stops, which provide shared space for people cycling and bus passengers. These have been added to manage conflicts between transit users and cyclists along the route.

With this study, it is wanted to pay attention to the very comprehensive aspect of the design and planning process for the bicycle path implemented in the city of Halifax and the management of the process by the local municipality, which receives the participatory support of the folks. In addition, in today's big cities where traffic congestion has become a big problem, it was wanted to emphasize the importance of a very comprehensive and multi-disciplinary approach to the issue by the municipalities, since the use of bicycles is an alternative mode of transportation and provides safe transportation during the pandemic process.

\section{Kaynakça/References}

Botma, H. (1995). Method to determine level of service for bicycle paths and pedestrian-bicycle path. Transportation Research Record, 1502, 38-44.

Eddy, N. (1996). Developing a level of service for bicycle use, In Pro Bike/Pro Walk 96 Resource Book, Proceedings of the Ninth International Conference on Bicycle and Pedestrian Programs Resource Book. Bicycle Federation of America and Pedestrian Federation of America.

Epperson, B. (1994). Evaluating suitability of roadways for bicycle use: toward a cycling level-of-service standard. Transportation Research Record, 1438, 9-16.

Halifax Regional Municipality. (2021). New street name suggestions for Cornwallis Street survey. Erişim adresi: https://www.halifax.ca/home/surveys

Halifax Regional Municipality. (2021). South Park protected bicycle lanes. Erişim adresi: $\quad$ https://www.halifax.ca/transportation/cycling-walking/expandingnetwork/south-park-protected-bicycle-lanes 
Halifax Regional and Transportation Standing Council. (2018). South Park bicycle lane extension and enhancement council report [PDF belgesi]. Erişim adresi: https://www.halifax.ca/sites/default/files/documents/city-hall/regionalcouncil/180306rc1432.pdf

Halifax Bike Map. (2021). Kanada, Nova Scotia eyaleti Halifax kenti bisiklet yolları haritasi.

Erişim adresi: https://www.arcgis.com/apps/webappviewer/index.html?id=a0c8d2ddd531482b $837 \mathrm{~b} 2 \mathrm{cf95b354e6b}$

Landis, B. W. (1997). Real-time human perceptions: toward a level of service. Presented at the transportation research board's 76th annual meeting, Washington, DC. National Research Council.

Nacto/National Association of City Transportation Officials. (2021). Urban bikeway design guide. Erişim adresi: https://nacto.org/publication/urban-bikeway-designguide

Sorton, A., Walsh, T. (1994). Bicycle stress level as a tool to evaluate urban and suburban bicycle compatibility, Transportation Research Record, 1438, 17-24.

Sorton, A. (1995). Measuring the bicyclist stress level of streets. In Transportation Congress: Civil Engineers--Key to the World Infrastructure. Proceedings of Conference. American Society of Civil Engineers. San Diego, CA.

Statistics Canada. (2017). Halifax'ın yüzölçümü. Erişim adresi: https://www12.statcan.gc.ca/census-recensement/2016/dp-pd/prof/det ils/page.cfm?Lang=E\&Geo1=CMACA\&Code1=205\&Geo2=PR\&Code2=12\&Data= Count\&SearchText=halifax\&SearchType=Begins\&SearchPR=01\&B1=All\&TABID $=1$

Transportation Association of Canada. (2021). Geometric design guide for Canadian roads. Erişim adresi: https://www.tac-atc.ca/en/publications-andresources/geometric-design-guide-canadian-roads

Turner, S., Shafer, C, S and Stewart, W. (1997). Bicycle suitability criteria for state roadways in Texas, Research Report of Texas Transportation Institute. The Texas A\&M University System College Station, Texas. 